\title{
Motivasi dan Strategi Belajar Siswa dalam Pendidikan Pembelajaran Berbasis Masalah dan Collaborative Learning di Fakultas Kedokteran Gigi Universitas Hasanuddin
}

\author{
Ayub Irmadani Anwar*, Yayi Suryo Prabandari**, Ova Emilia** \\ * Fakultas Kedokteran Gigi, Universitas Hasanuddin, Makasar \\ ** Program Studi S2 Ilmu Pendidikan Kedokteran, Fakultas Kedokteran, Universitas Gadjah Mada
}

\begin{abstract}
Background: Education providers in many ways short of expectations. Education strategy is essential in teaching and learning activities. Student who has motivation and learning strategies tends to devote all their ability to get the optimal learning results according to the expected goals.Understanding student motivation and learning strategies will help institution to facilitate students for their study success

Objective: The study aimed of determine differences in student motivation and learning strategies at Faculty of Dentistry, University of Hasanuddin among students with collaborative learning and problem based learning educational strategies. Methods: This was quantitative research with observational analytic cross-sectional study design. The subjects were all students of class 2007 and 2008 data were collected using Motivated Strategies for Learning Questionnaire (MSLQ). Descriptive analysis and Mann-Whitney test were used to analysis the data.

Results: The subjects consisted of 84 students of class 2007 and 79 students of class 2008. The mean score of learning motivation and learning strategy were higher among students with PBL than students with collaborative learning. There we are significant differences in learning strategies with different education strategies except in organization ( $p=$ $0,369)$ and anxiety $(p=0.058)$.

Conclusion: There are differences in the learning motivation and learning strategies in students with collaborative learning and problem based learning education strategies, except in organization and anxiety component. Learning motivation and learning strategies in problem based learning students are higher than collaborative learning students.
\end{abstract}

Keywords: Motivation and learning strategies, educational strategies.

\section{ABSTRAK}

Latar Belakang: Strategi pendidikan sangat penting dalam kegiatan belajar mengajar. Seseorang yang memiliki motivasi dan strategi belajar cenderung mencurahkan seluruh kemampuannya untuk mendapatkan hasil belajar yang optimal sesuai dengan tujuan yang diharapkan. Memahami motivasi dan strategi belajar mahasiswa dapat membantu memberikan informasi pada institusi untuk memfasilitasi keberhasilan studi.

Tujuan: Penelitian ini bertujuan mengetahui perbedaan motivasi dan strategi belajar mahasiswa Fakultas Kedokteran Gigi Universitas Hasanuddin pada mahasiswa dengan strategi pendidikan collaborative learning dan strategi pendidikan problem based learning.

Metode: Penelitian ini merupakan penelitian kuantitatif observasional analitik dengan rancangan penelitian potong lintang. Penelitian ini memakai total sampel. Pengumpulan data menggunakan instrumen Motivated Strategies for Learning Questionnaire (MSLQ). Analisis menggunakan analisis deskriptif dan Mann-Whitney.

Hasil: Sampel terdiri dari 84 mahasiswa angkatan 2007 dan 79 mahasiswa angkatan 2008. Skor minimal motivasi belajar dan strategi belajar mahasiswa dengan strategi PBL lebih tinggi disbanding mahasiswa collaborative learning. Terdapat perbedaan signifikan pada strategi belajar dengan strategi pendidikan berbeda, kecuali komponen organisasi $\mathrm{p}=0,369$ dan kecemasan $\mathrm{p}=0,058$.

Korespondensi: ayubanwar_mks@yahoo.com 
Kesimpulan: Ada perbedaan motivasi dan strategi belajar pada mahasiswa dengan strategi pendidikan collaborative learning dan problem based learning, kecuali dalam komponen organisasi dan komponen kecemasan. Motivasi dan strategi belajar pada mahasiswa problem based learning lebih besar nilai meannya dari mahasiswa collaborative learning.

Kata kunci: motivasi dan strategi belajar, strategi pendidikan.

\section{PENDAHULUAN}

Strategi pendidikan dapat diartikan sebagai perencanaan yang berisi rangkaian kegiatan yang didesain untuk mencapai tujuan pendidikan tertentu. Strategi pendidikan merupakan rencana tindakan (rangkaian kegiatan) termasuk penggunaan metode dan pemanfaatan berbagai sumber daya atau kekuatan dalam pembelajaran yang disusun untuk mencapai tujuan pembelajaran. Metode pembelajaran merupakan bagian dari strategi pendidikan, metode pembelajaran berfungsi sebagai cara untuk menyajikan, menguraikan, memberi contoh, dan memberi latihan kepada mahasiswa untuk mencapai tujuan tertentu, tetapi tidak setiap metode pembelajaran sesuai digunakan untuk mencapai tujuan pembelajaran tertentu. Strategi pendidikan merupakan hal yang perlu diperhatikan oleh seorang instruktur, guru/dosen, widyaiswara dalam proses pembelajaran. ${ }^{1}$

Menurut Collins dan O'Brien, student centred learning (SCL) yang diimplementasikan dengan benar akan meningkatkan motivasi untuk belajar pengetahuan dan pemahaman yang lebih mendalam, dan sikap positif terhadap subjek yang diajarkan. ${ }^{2}$ Selanjutnya student centered learning (SCL) dipahami sebagai suatu model pembelajaran yang menempatkan peserta didik sebagai pusat proses belajar. Dalam menerapkan konsep SCL, peserta didik diharapkan sebagai peserta aktif dan mandiri dalam proses pembelajaran, yang bertanggung jawab dan berinisiatif untuk mengenali kebutuhan belajarnya, menemukan sumber-sumber informasi untuk dapat menjawab kebutuhannya, membangun serta mempresentasikan pengetahuannya berdasarkan kebutuhan serta sumber-sumber yang ditemukannya. Dalam batas-batas tertentu peserta didik dapat memilih sendiri yang akan dipelajarinya. ${ }^{3}$

Melalui paparan teoritik yang telah dijelaskan dapat disimpulkan bahwa SCL adalah sebuah pendekatan pendidikan yang memfokuskan secara eksklusif pada kebutuhan, kemampuan, minat dan gaya belajar mahasiswa dalam proses pendidikan. Proses ini menempatkan dosen sebagai fasilitator.

Pada SCL terdapat paradigma bahwa pembelajaran menjadi lebih interaktif dan integratif, tidak terfokus hanya pada hal yang dipelajari tetapi juga cara pengetahuan tersebut bisa didapat, dapat mengetahui ilmu dasar, dan pelajar bertanggungjawab dan memegang kendali atas tujuan belajar. Dengan demikian, dosen hanya berperan sebagai fasilitator atau manajer dari pembelajaran. ${ }^{4}$ SCL menekankan pentingnya collaborative learning. Collaborative learning adalah sebuah metode belajar yang berarti bekerja dalam kelompok untuk mencapai tujuan bersama, menghormati masing-masing individu pada kelompok. Sejumlah penelitian telah menunjukkan bahwa belajar melalui collaborative dibandingkan dengan pembelajaran kompetitif atau individu, biasanya menghasilkan prestasi yang lebih tinggi, lebih baik hubungan psikologisnya (merawat, dukungan, dan komitmen), kompetensi sosial, dan harga diri. ${ }^{5}$

Salah satu bentuk SCL adalah pendekatan pembelajaran berbasis masalah yang dikenal dengan istilah problem based learning (PBL). Pada awalnya dirancang untuk program graduate bidang kesehatan. ${ }^{6}$ PBL adalah pendekatan learner-centered menurut Santrock (2011). ${ }^{7}$ Dalam problem based learning, perencanaan dan instruksinya sangat berbeda dengan pendekatan teachercentered. PBL dikembangkan berdasarkan teori psikologi kognitif modern yang menyatakan bahwa belajar adalah merupakan suatu proses pembelajar secara aktif mengkonstruksi pengetahuannya melalui interaksinya dengan lingkungan belajar yang dirancang oleh fasilitator pembelajaran. Teori yang dikembangkan ini mengandung dua prinsip penting, yaitu: 1) belajar adalah suatu proses konstruksi bukan proses menerima (receptive 
process), 2) belajar dipengaruhi oleh faktor interaksi sosial dan sifat kontektual dari pelajaran. Wim, menjelaskan teori ini mengisyaratkan dalam pembelajaran terdapat proses konstruksi pengetahuan oleh pembelajar, terjadi interaksi sosial baik antar mahasiswa maupun dosen serta materi perkuliahan yang bersifat kontektual. Berdasarkan dua prinsip yang terkandung dalam PBL tersebut, dosen harus mampu memberikan kondisi terjadinya kesempatan yang luas bagi mahasiswa untuk mengkonstruksi pengetahuan yang ingin dipelajarinya. ${ }^{8}$

Menurut Hastings, problem based learning dapat memotivasi mahasiswa untuk melakukan investigasi dan pemecahan masalah pada situasi kehidupan nyata serta dapat merangsang mahasiswa untuk menghasilkan sebuah produk/karya. Problem based learning dikembangkan untuk membantu mahasiswa mengembangkan kemampuan dalam berpikir kritis, memecahkan masalah dan keterampilan intelektual. Problem based learningjuga dapat mengembangkan keterampilan berpikir kritis dan analisis serta memberikan mahasiswa latihan untuk memecahkan masalah. ${ }^{9}$

Motivasi belajar tidak akan terbentuk apabila orang tersebut tidak mempunyai keinginan, cita-cita atau menyadari manfaat belajar bagi dirinya. Oleh karena itu, dibutuhkan pengkondisian tertentu, agar setiap orang memiliki semangat untuk belajar dan termotivasi. Berdasar berbagai pengertian di atas, dapat disimpulkan bahwa motivasi belajar adalah tenaga yang menggerakkan dan mengarahkan aktivitas belajar mahasiswa dalam usaha pencapaian tujuan belajar. Selanjutnya, motivasi belajar adalah aspek psikologi seseorang yang ditentukan dengan gejala seperti: gairah, keinginan, dan dorongan untuk melakukan proses perubahan tingkah laku melalui berbagai kegiatan mencari pengetahuan dan pengalaman. ${ }^{10}$ Seorang dosen yang baik perlu memotivasi mahasiswa untuk terus belajar dan mengajarkan keterampilan dan strategi belajar yang diperlukan. ${ }^{11}$

Pemilihan strategi belajar mengajar harus dilandaskan pada pertimbangan menempatkan siswa sebagai subjek belajar yang tidak hanya menerima secara pasif yang disampaikan oleh guru. Guru harus menempatkan siswanya sebagai insan yang secara alami memiliki pengalaman, pengetahuan, keinginan, dan pikiran yang dapat dimanfaatkan untuk belajar, baik secara individual maupun berkelompok. Strategi yang dipilih oleh dosen adalah strategi yang dapat membuat mahasiswa mempunyai keyakinan bahwa dirinya mampu belajar dengan memanfaatkan potensi mahasiswa. ${ }^{12}$

Instrumen yang banyak digunakan untuk strategi pendidikan adalah motivated strategies for learning questionnaire (MSLQ) yang dikembangkan oleh Pintrich, Smith, Garcia, dan McKeachie. ${ }^{13}$ Instrumen ini telah digunakan luas dalam berbagai disiplin ilmu, tetapi sedikit yang diketahui pada penggunaan mengenai strategi pendidikan dan prestasi dalam sistem informasi. Dengan informasi ini, dosen dapat membuat mahasiswa menyadari strategi belajar yang efektif diberbagai jenis lingkungan belajar dan membantu mahasiswa untuk menggunakan strategi pembelajaran yang tepat.

Peran motivasi dalam belajar telah terbukti melalui penelitian yang luas dihampir semua tingkat pendidikan Pintrich dan De Groot. ${ }^{14}$ Motivasi dapat mempengaruhi hal, waktu dan cara seseorang belajar dan menanggung hubungan timbal balik untuk belajar dan bekerja, yang mempengaruhi motivasi belajar dan bekerja pada siswa terhadap pengaruh motivasi belajar mereka.

Tujuan penelitian ini adalah untuk mengetahui perbedaan motivasi dan strategi belajar mahasiswa Fakultas Kedokteran Gigi Universitas Hasanuddin pada mahasiswa dengan strategi pendidikan collaborative learning dan strategi pendidikan problem based learning.

\section{METODE}

Penelitian ini merupakan penelitian kuantitatif observasional analitik dengan rancangan potong lintang. Populasi penelitian ini adalah mahasiswa angkatan 2007 dan angkatan 2008 yang masih aktif mengikuti perkuliahan di Fakultas Kedokteran Gigi Universitas Hasanuddin. Mahasiswa angkatan 2007 adalah angkatan terakhir yang mengikuti strategi pembelajaran SCL dengan sistem collaborative learning, dan mahasiswa angkatan 2008 adalah angkatan pertama yang mengikuti strategi pembelajaran SCL sistem problem based learning.

Penelitian ini memakai total sampel karena jumlahnya cukup terjangkau. Pengambilan data dilakukan dengan menggunakan data primer yang berasal dari kuesioner yang dibagikan dan diisi oleh mahasiswa. 
Pengumpulan data menggunakan instrumen motivated strategies for learning questionnaire (MSLQ) dengan skala Likert. Instrumen MSLQ dari Pintrich, Smith, Garcia dan Mc Keachie ${ }^{13}$ memungkinkan peneliti untuk mengetahui dan menilai orientasi motivasional dan strategi belajar mahasiswa. Hal tersebut memungkinkan penilaian terintegrasi kognitif, metakognitif dan motivasi. Terdapat dua komponen MSLQ, yaitu komponen motivasi dan komponen strategi belajar. Komponen motivasi belajar terdiri dari 31 butir yang menilai tujuan dan nilai yang diyakini mahasiswa terhadap mata kuliah tertentu, keyakinan tentang kemungkinannya untuk sukses dalam perkuliahan, dan kekhawatiran akan ujian. Komponen strategi belajar terdiri dari 31 butir yang berhubungan dengan cara mahasiswa menggunakan strategi kognitif dan metakognitif. Sebagai tambahan, komponen strategi belajar mencakup 19 butir yang bertujuan untuk melihat tata kelola mahasiswa terhadap berbagai sumber. Dengan demikian MSLQ memiliki 81 butir, dari 81 butir MSLQ, mahasiswa mengukur dirinya sendiri dalam tujuh poin skala Likert, dari poin satu (tidak benar sama sekali untuk saya) sampai poin tujuh (sangat benar untuk saya). ${ }^{14}$

Skor untuk skala individu dihitung dengan mengambil rata-rata komponen yang masuk ke skala tersebut. Misalnya, tes skala kecemasan terdiri dari lima pertanyaan. Skor seorang mahasiswa dihitung dengan menjumlah kelima pertanyaan dan dihitung rata-ratanya. MSLQ berguna, reliabel dan valid untuk menilai motivasi dan kegunaan strategi pembelajaran mahasiswa dalam kelas.

Dalam penelitian ini analisis data memakai: analisis deskriptif untuk mendeskripsikan motivasi belajar dan strategi belajar mahasiswa Fakultas Kedokteran Gigi Universitas Hasanuddin dan uji Mann-Whitney digunakan untuk menguji hipotesis penelitian.

\section{PEMBAHASAN}

Penelitian ini melibatkan 84 mahasiswa angkatan 2007 dan 79 mahasiswa angkatan 2008 yang masih aktif kuliah di Fakultas Kedokteran Gigi Universitas Hasanuddin.

Tabel 1. Deskripsi kelompok sistem strategi pendidikan collaborative learning dan strategi pendidikan problem based learning

\begin{tabular}{lcccc} 
& \multicolumn{2}{c}{ Collaborative learning $(\mathrm{n}=84)$} & Problem based learning $(\mathrm{n}=79)$ \\
\cline { 2 - 5 } Variabel & $\mathrm{n}$ & $(\%)$ & $\mathrm{n}$ & $\%$ \\
Jenis kelamin : & & & & \\
Taki-I aki & 22 & $(26.2)$ & 18 & $(22.8)$ \\
Perempuan & 62 & $(73.8)$ & 61 & $(77.2)$ \\
\hline
\end{tabular}

Tabel 1 menunjukkan bahwa pada kedua kelompok, jumlah mahasiswa perempuan lebih banyak. Kelompok mahasiswa dengan strategi pendidikan Collaborative learning berjumlah 84 mahasiswa terdiri dari laki-laki 22 mahasiswa (26,2\%) dan mahasiswa perempuan sebanyak
62 mahasiswa (73,8\%). Kelompok mahasiswa yang menggunakan strategi pendidikan problem based learning berjumlah 79 mahasiswa terdiri dari laki-laki berjumlah 18 mahasiswa $(22,8 \%)$ dan perempuan 61 mahasiswa $(77,2 \%)$. 
Tabel 2. Karakteristik MSLQ komponen motivasi belajar

\begin{tabular}{lccc} 
& & \multicolumn{2}{c}{ Jenis kelamin } \\
\cline { 3 - 4 } \multicolumn{1}{c}{ Variabel } & Mean (SD) & $\begin{array}{c}\text { Laki-laki } \\
\text { Mean (SD) }\end{array}$ & $\begin{array}{c}\text { Perempuan } \\
\text { Mean (SD) }\end{array}$ \\
Komponen nilai : & & & \\
Orientasi tujuan intrinsik & $5,07(1,14)$ & $5.14(1.19)$ & $5.05(1.12)$ \\
Orientasi tujuan ekstrinsik & $5,72(1,15)$ & $5.56(1.15)$ & $5.77(1.15)$ \\
Nilai Tugas & $5,41(0,99)$ & $5.25(1.00)$ & $5.46(0.99)$ \\
Komponen harapan : & & & \\
Kontrol kepercayaan belajar & $5,43(1,04)$ & $5.40(1.09)$ & $5.44(1.03)$ \\
Kepercayaan diri untuk belajar \& prestasi & $4,52(1,00)$ & $4.65(1.11)$ & $4.48(0.96)$ \\
\hline
\end{tabular}

Pada Tabel 2 terdapat karakteristik MSLQ variabel motivasi belajar memperlihatkan orientasi tujuan ekstrinsik memiliki angka mean yang tertinggi 5,72 (1,15) dan kepercayaan diri untuk belajar dan prestasi angka mean terendah $4,52(1,00)$.

Tabel 3. Karakteristik MSLQ komponen strategi belajar

\begin{tabular}{lccc} 
& & \multicolumn{2}{c}{ Jenis kelamin } \\
\cline { 4 - 4 } \multicolumn{1}{c}{ Variabel } & Mean (SD) & $\begin{array}{c}\text { Laki-laki } \\
\text { Mean (SD) }\end{array}$ & $\begin{array}{c}\text { Perempuan } \\
\text { Mean (SD) }\end{array}$ \\
Strategi kognitif \& metakognitif: & & & \\
Pengulangan & $4,51(1,11)$ & $4.24(0.86)$ & $4.60(1.17)$ \\
Elaborasi & $4,50(1,16)$ & $4.57(1.08)$ & $4.47(1.18)$ \\
Organisasi & $4,24(1,23)$ & $3.95(1.28)$ & $4.33(1.20)$ \\
Kecemasan & $4,33(1,16)$ & $4.64(1.04)$ & $4.22(1.19)$ \\
Metakognitif pengaturan diri & $4,53(0,89)$ & $4.47(0.90)$ & $4.55(0.90)$ \\
Strategi manajemen sumber : & & & \\
Waktu \& lingkungan belajar & $4,71(0,82)$ & $4.74(0.74)$ & $4.70(0.84)$ \\
Pengaturan usaha & $4,69(0,95)$ & $4.56(0.88)$ & $4.74(0.97)$ \\
Mencari pertolongan & $4,63(0,91)$ & $4.71(0.95)$ & $4.61(0.89)$ \\
Rekan belajar & $4,59(1,23)$ & $4.51(1.17)$ & $4.62(1.25)$ \\
\hline
\end{tabular}

Pada Tabel 3 memperlihatkan karakteristik MSLQ komponen strategi belajar dengan waktu dan lingkungan belajar memiliki angka mean tertinggi $4,71(0,82)$ dan terendah pada organisasi 4,24 (1,23).

Tabel 4. Komponen motivasi belajar mahasiswa berdasarkan strategi pendidikan

\begin{tabular}{lccc}
\multicolumn{1}{c}{ Variabel } & $\begin{array}{c}\text { Collaborative } \\
\text { learning }(\mathrm{n}=84)\end{array}$ & $\begin{array}{c}\text { Problem based } \\
\text { learning }(\mathrm{n}=79)\end{array}$ & Nilai P \\
\hline Komponcn nilai : & 69,78 & 94,99 & $0,001^{*}$ \\
Oricntasi tujuan intrinsik & 64,94 & 100,14 & $0,000^{*}$ \\
Orientasi tujuan ekstrinsik & 68,77 & 96,06 & $0,000^{*}$ \\
Nilai tugas & & & \\
Komponen harapan : & 65,97 & 99,04 & $0,000^{*}$ \\
Kontrol kepercayaan belajar & 69,99 & 94,77 & $0,001^{*}$ \\
\hline Kepercayaan diri untuk belajar \& prestasi & & & \\
\hline
\end{tabular}

Menggunakan uji Mann Whitney dengan tingkat kemaknaan 5\% ( $\mathrm{p}<0.05)$,

* bermakna $(\mathrm{p}<0.05)$ 
Pada Tabel 4 memperlihatkan perbedaan semua variabel motivasi belajar mahasiswa dengan strategi pendidikan baik collaborative learning maupun problem based learning.
Terlihat mean pada strategi pendidikan problem based learning lebih besar dari pada strategi pendidikan collaborative learning.

Tabel 5. Komponen strategi belajar mahasiswa berdasarkan Strategi Pendidikan

\begin{tabular}{lccc}
\multicolumn{1}{c}{ Variabel } & $\begin{array}{c}\text { Collaborative } \\
\text { learning }(\mathrm{N}=84)\end{array}$ & $\begin{array}{c}\text { Problem based } \\
\text { learning }(\mathrm{N}=79)\end{array}$ & Nilai P \\
\hline Strategi kognitif \& metakognitif: & & & \\
Pengulangan & 72,02 & 92,61 & $0,005^{*}$ \\
Elaborasi & 70,65 & 94,06 & $0,002^{*}$ \\
Organisasi & 78,79 & 85,42 & 0,369 \\
Kecemasan & 75,21 & 89,22 & 0,058 \\
Metakognitif pengaturan diri & 72,42 & 92,18 & $0,008^{*}$ \\
Strategi manajemen sumber: & & & \\
Waktu \& lingkungan belajar & 63,77 & 101,38 & $0,000^{*}$ \\
Pengaturan usaha & 74,73 & 89,73 & $0,042^{*}$ \\
Mencari pertolongan & 72,07 & 92,56 & $0,005^{*}$ \\
Rekan belajar & 67,59 & 97,32 & $0,000^{*}$ \\
\hline
\end{tabular}

Menggunakan uji Mann Whitney dengan tingkat kemaknaan $(\mathrm{p}<0.05)$

Tabel 5 memperlihatkan perbedaan bermakna strategi belajar pada mahasiswa dengan strategi pendidikan collaborative learning dan problem based leaming kecuali dalam hal organisasi $p=0,369$ dan kecemasan $p=0,058$. Terlihat pada strategi pendidikan problem based learning lebih besar nilai meannya dari pada strategi pendidikan collaborative learning.

Pada sampel penelitian diperoleh lebih banyak perempuan baik pada mahasiswa angkatan 2007 maupun mahasiswa angkatan 2008 Fakultas Kedokteran Gigi Universitas Hasanuddin. Hal ini kemungkinan disebabkan karena profesi Kedokteran Gigi adalah suatu profesi yang secara historis didominasi perempuan. Mean skor pada kelompok PBL memiliki nilai lebih tinggi dibandingkan kelompok collaborative learning. Hal ini belum tentu menunjukkan perbedaan nilai yang sesungguhnya karena mahasiswa yang diteliti berasal dari kelompok yang berbeda.

Semua sampel penelitian ini termasuk usia dewasa muda. Sesuai dengan penelitian Knowles, E. \& Kerkman, D ${ }^{15}$ mahasiswa usia dua puluhan memiliki orientasi tujuan motivasi ekstrinsik yang lebih tinggi. Fenomena ini muncul pada mahasiswa PBL, dimana mean orientasi ekstrinsik lebih besar dibandingkan orientasi instrinsik.
Hal ini berbeda dengan asumsi bahwa PBL akan memacu motivasi instrinsik mahasiswa. Motivasi intrinsik umumnya mencakup keinginan untuk belajar mendalam tentang topik tertentu. Vansteenkiste at al. menunjukkan motivasi intrinsik pada mahasiswa meningkatkan meraih nilai yang lebih tinggi, dan lebih mendorong ketekunan mahasiswa dengan motivasi ekstrinsik. Demikian juga sesuai dengan penelitian Mardining ${ }^{16}$ dalam proses PBL peranan motivasi baik internal maupun eksternal sangat diperlukan. Motivasi belajar yang ada pada mahasiswa akan mengembangkan aktivitas, inisiatif dan kreativitas, serta mengarahkan kesungguhan dalam kegiatan belajar. Tanpa motivasi belajar mahasiswa tidak dapat mengikuti proses belajar dengan baik.

\section{KESIMPULAN}

Ada perbedaan motivasi dan strategi belajar pada mahasiswa Fakultas Kedokteran Gigi Universitas Hasanuddin dengan strategi pendidikan collaborative learning dan problem based learning. Motivasi dan strategi belajar mahasiswa pada strategi pendidikan problem based learning lebih besar dibanding mahasiswa dengan strategi pendidikan collaborative learning. 


\section{DAFTAR PUSTAKA}

1. Majid, A. Strategi pembelajaran, PT. Remaja Rosdakarya Offset, Cetakan pertama, Bandung. 2013: 174-180.

2. Widhiarso. Validasi model kompetensi dosen dalam pembelajaran berbasis student centered learning. Tesis. Fakultas Psikologi Universitas Gajah Mada. 2010.

3. Pongtuluran, A. Student-centered learning: the urgency and possibilities. Petra Christian University. 1999: 2 10.

4. Smith, B.L. \& Mac Gregor J.T. What is collaborative learning? In: Collaborative learning: A Sourcebook for higher education National Centre, Pennsylvania State University, Washington center for improving the quality of undergraduate education. 1992: 1-11.

5. An, H., Kim S. \& Kim B. Teacher perspectives on online collaborative learning: Factors perceived as facilitating and impeding successfull online group work. Contemporary Issue in Technology and Teacher Education, 2008; 8(1): 65-83.

6. Howard S. Barrows MD and Robyn MT. ProblemBased Learning: An approach to medical education (Springer Series on Medical Education). 1980.

7. Santrock J., NY, McGraw-Hill. Educational Psychology, 2011.

8. Suci, N.M. Penerapan model problem based learninguntuk meningkatkan partisipasi belajar dan hasil belajar teori akuntansi mahasiswa jurusan Ekonomi Undiksha, Jurnal Penelitian dan Pengembangan Pendidikan, Lembaga Penelitian Undiksha. 2008; 2(1): 21-34.

9. Arnyana. Pengembangan perangkat model belajar berdasarkan masalah dipandu strategis kooperatif serta pengaruh implementasinya terhadap kemampuan berpikir kritis dan hasil belajar siswa sekolah menengah atas pada pelajaran ekosistem. Malang, tesis. Program Pasca Sarjana Universitas Negeri Malang. 2004.

10. Giyanto. Pengaruh metode pembelajaran dan motivasi belajar terhadap kompetensi komunikasi terapetik mahasiswa program profesi ners. Tesis, Program Studi Kedokteran Keluarga, Program Pascasarjana Universitas Sebelas Maret Surakarta, 2010: 11-21.

11. McKeachie. Learning styles can become learning strategies, Journal on line of The National Teaching \& Learning. 1995; 4(6): 1-3.

12. Ghazali, A.S. Strategi belajar kooperatif dalam belajar mengajar kontektual. Jurnal Pendidikan \& Pembelajaran. 2002; 9(1): 49-60.

13. Pintrich, P. R., Smith, D. A. F., Garcia, T., \& McKeachie, WJ. A manual for the use of the motivated strategies for learning questionnaire (MSLQ). Ann Arbor, MI: National Center for Research to Improve Postsecondary Teaching and Learning. 1991

14. Pintrich, P. R., \& De Groot, E. V. Motivational and self-regulated learning components of classroom academic performance. Journal of Educational Psychology. 1990; 82(1): 33-40.

15. Knowles, E. \& Kerkman D. An investigation of students attitude and motivation toward online learning. In sight: A collection of Faculty Scholarship, Student Motivation. 2007; 2: 70-80.

16. Mardining, T. Pengaruh metode problem based learning pada motivasi belajar siswa pada pembelajaran PKN di SMP Negeri 11 Yogyakarta, Thesis, Program studi magister manajemen, Fakultas Ekonomika dan Bisnis Universitas Gadjah Mada. 2012; 27-59 